\title{
APPLICATION OF EARNED VALUE BASED METRICS ON SMALL-SCALE CONSTRUCTION PROJECTS
}

\author{
Radoslav Avlijaš*, Goran Avlijaš, Milenko Heleta
}

Singidunum University, 32 Danijelova St., Belgrade, Serbia

\begin{abstract}
:
The application of earned value based metrics in Serbia lags significantly behind other developed economies, regardless of the fact that is has proven to be a very useful and flexible tool for prediction of total cost and time of construction projects. This paper aims to contribute to the wider use of earned value management (EVM) as a practical metrics that can be used to track performance of small-scale construction projects. Literature review reveals how the method evolved as a fundamental tool for construction projects monitoring and refers to specific issues concerning its implementation. In order to enable practitioners to realize all advantages of earned value based performance monitoring of small-scale construction projects, the applicability of such methodology is demonstrated through a case study.
\end{abstract}

EJAE 2015, 12(2): 1-8

ISSN 2406-2588

UDK: 005.8:728.224(497.11)"2002/2014"

005.52:330.133.1

DOI: $10.5937 /$ ejae12-8515

Original paper/Originalni naučni rad

\section{Key words:}

earned value,

project management,

construction.

\section{INTRODUCTION}

The main objective of project management is to fulfill all project requirements within budget forecasts and the planned time-line (Avlijaš \& Avlijaš, 2010). In order to achieve this goal, project team has to devote significant managerial efforts. One of the most important steps in this process is development of the effective performance monitoring system. In that sense, performance monitoring primarily relates to monitoring of cost, time and quality of the construction project. Regardless of how carefully the project plan was developed, it is not possible to assess the project progress and effectiveness of execution, as well as performance of the entire construction project, without timely and regular performance control (Yang et al., 2010).

Project teams strive to control three key performance indicators (KPIs) related to construction projects: cost, time and scope. These KPIs constitute the "triple constraint" of any project, and timely monitoring of these values enables project teams to maintain the required level of construction project quality. Namely, project monitoring is an iterative process, during which the actual values are compared to the planned values in order to predict the overall project cost and time and undertake any preventive and corrective measures based on these predictions (PMI, 2013).

One of the biggest challenges related to constructive project monitoring is the selection of the appropriate monitoring methodology. In fact, project teams on most of construction projects in the world use the simple comparison of planned to actual costs. This approach does not take into account the value of the work performed, which omits the third dimension of costs: the earned value of the work (Fleming \& Koppelman, 2003). The monitoring methodology that enables integration of the work performed with the planned and actual project time and costs, and quantification of project technical performance is Earned Value Management (EVM). 
EVM methodology has been extensively applied in the field of military industry, energy and software engineering, and its use is increasingly growing (Kim et al., 2003). However, the implementation of this very useful and effective control tool in the construction industry lags behind other industries, especially when it comes to small scale projects. The reasons for poor implementation of EVM methodology in the construction industry in European region are not yet fully known, since there are very few academic papers dealing with this issue. Regarding that, it is believed that more significant academic effort should contribute to wider adoption of EVM by practitioners and civil engineers (De Marco \& Narbaev, 2013).

This paper aims to reduce the gap between theory and practice and contribute to the wider use of EVM methodology in the construction industry in Serbia. In addition, by using a short case study, the paper demonstrates the application of the methodology on a small-scale construction project. The paper is organized as follows. The following section points out to the importance of construction projects efficiency within the global and local economy. The third section provides a short presentation of EVM methodology, which covers the basic concepts, as well as the main advantages and disadvantages. Finally, after demonstration of EVM methodology on a small scale construction project, the paper concludes with a short discussion of the research findings and conclusions.

\section{(IN)EFFICIENCY OF CONSTRUCTION PROJECTS}

Even though the area of construction management has been widely explored for decades, construction industry worldwide is still considered very inefficient. Today, along with the rapid development of technology, higher quality standards of the final product and increasing competition, there are many obstacles to achieving the project goals. Construction industry performance seems to be considerably lagging behind other industries. Competitive, political and economic pressures contained in the industry, call for changes in the implementation of construction projects.

Looking from the aspect of the local economy, the future of the construction industry does not seem promising at the moment. In the period from 2006 to 2011, Serbian construction industry expected annual growth of $15-20 \%$, and a significant increase in construction work was recorded both in the domestic and export markets (Trbović et al., 2007). Sales in 2006 were $120 \%$ higher than in 2002 , while the value of construction works abroad in 2006 totaled \$ 138 million, which is an increase of $64 \%$ compared to 2005 (Trbović et al., 2007).

However, due to the global financial crisis, the situation in the construction industry worldwide rapidly deteriorated and negative effects did not bypass Serbian companies. As can be seen in Figure 1, the value of construction works significantly declined (Statistical Office of the Republic of Serbia, 2015). According to the official data, 2,000 Serbian construction companies were shut down in 2008 , and about 20,000 workers in the construction sector lost their jobs.

Competitive pressure has reached a point where only an extremely efficient and profitable enterprise can ensure itself a long-term survival and development. According to the Serbian Chamber of Commerce, construction industry in Serbia accounts for about 11,530 companies and 116,760 workers. Construction firms participate in the total number of companies and in the total number of employees with $13.1 \%$ and $11.8 \%$, respectively (Serbian Chamber of Commerce, 2015). Having in mind that construction industry in Serbia supplies more than 30 other

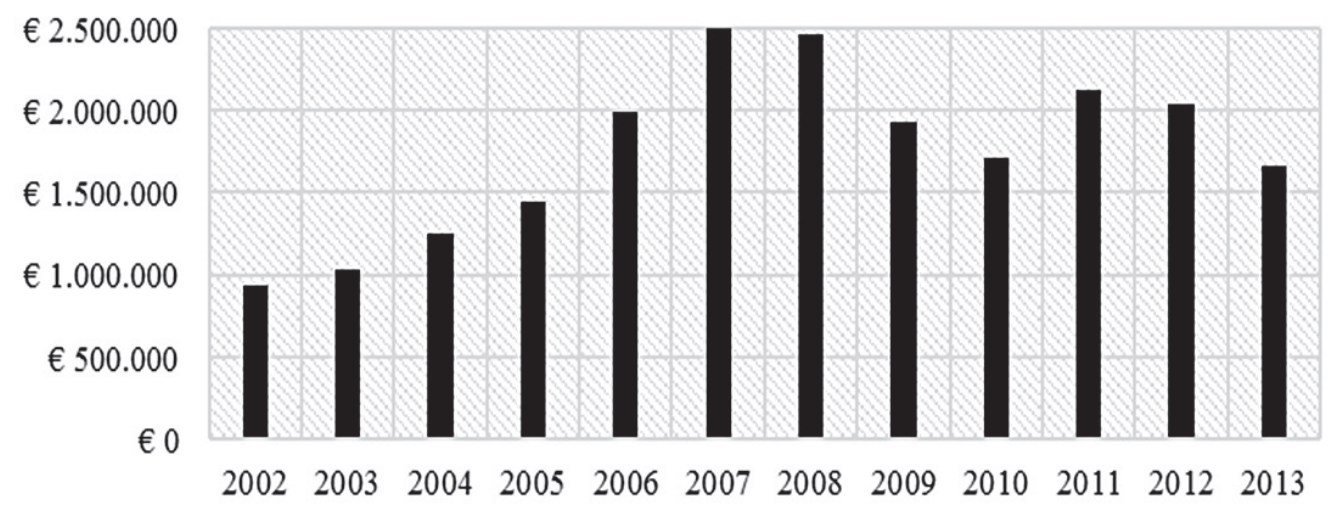

Figure 1. Total value of executed construction works in the Republic of Serbia (in thousands) 
industries with different inputs, it can be concluded that the performance of construction companies and their projects have a significant impact on the national economy (Mladenović, 2013).

Serbian construction companies are usually less efficient than foreign companies, as they employ too many workers (Trbović et al., 2007) and domestic laws cannot cope with numerous challenges of modern business (Mladenović, 2013). Poor efficiency is primarily related to significant total project time and cost overrun. In addition to the known threats in the form of technical and external risks, there is an increasing number of recent projects being unsuccessful due to different types of organizational risks. By studying the organizational risks, practitioners report the low level of management skills and insufficient use of modern methods and information systems in the project planning and monitoring phase, as one of the most common causes of failure to meet deadlines and budgets.

On a global scale, exceeding of the planned cost represents a trend that has not changed for almost 70 years (Flyvbjerg et al., 2002). According to a survey encompassing 258 capital projects in 20 countries worth a total of $\$ 90$ billion, 9 out of 10 projects recorded cost overruns (average overrun of 28\%). The study included America, Europe, Japan and other countries where the average cost overrun was $64 \%$. The results show that $44 \%$ of liability is applied to contractors, $24 \%$ to investors, $14 \%$ to legislature, shared responsibility was observed in $12 \%$ of cases, while responsibility applied to consultants was observed in $6 \%$ of cases. The most alarming is the fact that $48 \%$ of costs were justifiedpayable, $8 \%$ justified - unpayable, and $44 \%$ completely unjustified (Flyvbjerg et al., 2002).

Different types of construction projects in Saudi Arabia were examined in order to determine significant causes of delay. The survey included 15 owners, 23 contractors and 19 consultants, and the results showed that the average of time overrun ranges between $10 \%$ and $30 \%$ of original duration. The survey concluded that $70 \%$ of projects experienced time overrun and found that 45 out of 76 projects considered were delayed (Assaf \& Al-Hejji, 2006).

Doloi et al. (2012) used regression modeling to examine the critical factors that can affect cost performance in both - the preconstruction and construction phases of Indian projects. Some of the significant factors were: accurate project planning and monitoring, contractors' efficiency, effective site management, design and communication efficiency on construction projects.
In most of the cases, construction project planning is performed by means of a rough estimate of time frames and budgets, and unidentified risks always affect the degree of accomplishment of project requirements. Practice has shown that monitoring and control of project execution often involve a simple comparison of actual time and costs with the planned values, which does not take into account the actual value of the works completed to a certain point and does not provide a realistic picture of the time and cost of performance. No matter if it is the domestic or foreign market, it is clear that construction companies must adopt a more adequate approach to project management that will be able to respond to all challenges of the constantly changing environment.

\section{BENEFITS AND ISSUES IN EVM APPLICATION}

The Earned value concept was developed in 1967 by the Ministry of Defense of the United States, first as a system of 35 criteria for cost and time control (Cost/Schedule Control Systems Criteria - C/SCSC). At the very beginning, C/SCSC was considered exclusively as a tool for financial control, which could be used in project management. However, in 1989, the Ministry of Defense adopted the criteria system as an official tool for managing programs and procurement activities, and since the mid-nineties, the system has recorded a wider application in public administration (energetics, information technology, space exploration, construction, etc.) and got the new name - Earned Value Management.

Earned Value Management (EVM) is one of the most significant methods used in the process of monitoring and control of project performance (PMI, 2011). The original concept of earned value was derived from the industrial engineering methods, which in detail analyzed "cost-performance" approach. In the process of cost-effectiveness assessment, the comparison of planned and actual values of time and cost was carried out. Over the time, the application of this methodology was not limited only to government industrial and military projects, but is still relatively poorly applied to commercial and private projects (Kwak \& Anbari, 2012).

The importance of the Earned Value Management is that it provides an accurate measure of the cost and time performance in the process of project monitoring and control. Scientific studies conducted by Christensen and his associates in the period 1998-2002, show that the CPI indicator measured at the $15-20 \%$ 
of project completion, provides a sufficiently reliable measure for prediction of total project cost with a maximum error of $\pm 10 \%$ (Christensen, 1998, 1999; Christensen \& Heise, 1993; Christensen \& Templin, 2002). In this regard, the EVM may constitute a means of early warning at just $20 \%$ of project completion. Nevertheless, the application of the EVM methodology in the construction industry is still at a very low level (De Marco \& Narbaev, 2013).

Some of the most common problems in the application of EVM methodology that practitioners state include: the necessity of a detailed plan before the project starts, reliable performance measure and reporting, difficulties in measuring actual physical progress of construction activities, and accurate input data (Wilson et al., 2013). Despite the fact that there are many arguments that the EVM is difficult to apply to small scale construction projects, it has become increasingly accepted as an important and effective method for monitoring various types of projects, regardless of the project size or risk. Therefore, the key factors of successful implementation of EVM methodology are the choice of the right format and its adaptation to monitoring and control of a specific project.

The Earned value analysis is based on the three key values: Budgeted Cost of Work Scheduled (BCWS), Budgeted Cost of Work Performed (BCWP), also known as Earned Value (EV) and Actual Cost of Work Performed (ACWP). The fourth extra value refers to the total planned budget of the project (Budget at Completion), which represents the BCWS of the entire project. Based on these values, variances were derived, i.e. the difference between the planned and actual values, which can be used as indicators of performance and a tool for predicting the total project time and cost.

BCWS values for each project activity serve as the basis as BCWP and ACWP values are compared throughout the project's life cycle. The difference between planned and actual values is measured using two variances that provide accurate positive or negative image of financial project performance. Cost variance $(\mathrm{CV})$ represents a measure of budgetary conformance of $\mathrm{AC}$ and is calculated as the difference between the earned value and actual cost (CV=EV-ACWP). Schedule variance (SV) represents the difference between earned and planned value (SV=EV-BCWS). Overall, the positive values of variances mean that the project is implemented within the budget and planned time frame, while negative values mean that the project is over budget and behind schedule.

On the other hand, the performance indicators do not provide a monetary value, but can be used as indicators of actual performance. They represent ratios of planned and earned values in case of cost performance index, and actual and earned values in case of schedule performance index. Cost performance index (CPI) can be used to estimate the project cost $(\mathrm{CPI}=1$ means that project costs just as much as planned; $\mathrm{CPI}<1$ project is over budget; CPI $>1$ project costs less than planned). Similarly, the schedule performance index (SPI) can be used to estimate the project completion time (SPI $=1$ means that the project is executed in accordance with the time schedule; SPI $>1$ the project is executed faster than planned; $\mathrm{SPI}<1$ project is late compared to the schedule).

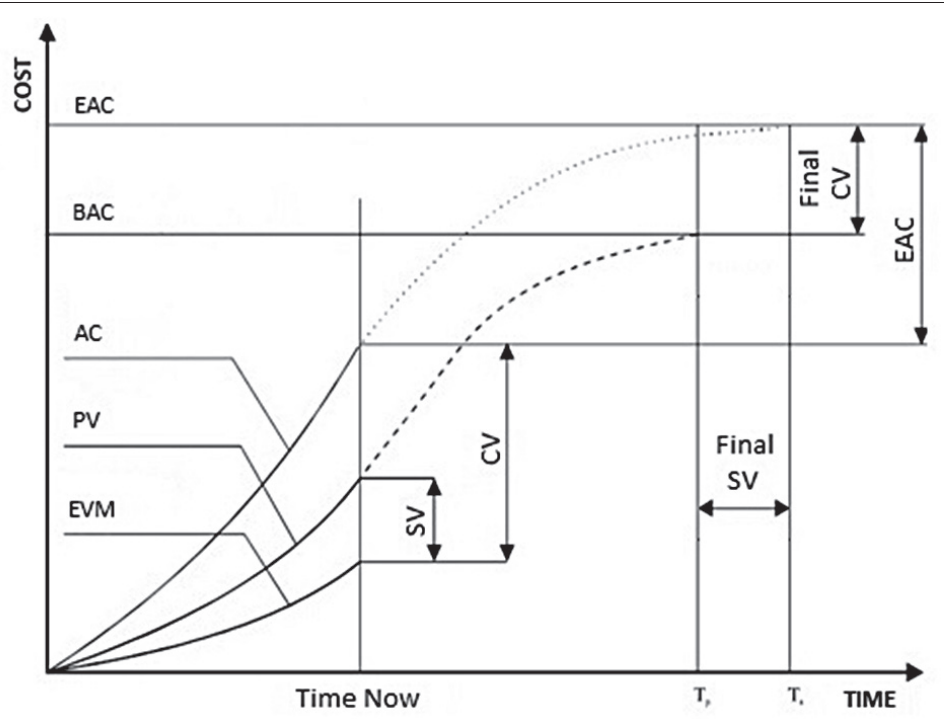

Figure 2. Variances and indexes used in Earned Value Management 
Calculation of two variables - Estimate at Completion (EAC) and the Time Estimate at Completion (TEAC) is a precondition for project execution in a planned way. Already described indicators, CPI and SPI, are used for calculation of the EAC and TEAC values, which represent the projection of the current project progress to the rest of the project execution. The two most common ways of calculating the EAC and TEAC values are: $\mathrm{EAC}=\mathrm{BAC} / \mathrm{CPI}$ and $\mathrm{TEAC}=\mathrm{D} / \mathrm{SPI}$, where $\mathrm{BAC}$ represent the total projected cost of the project, and D total scheduled time of project. The described indicators are shown in Figure 2.

Although these measures are generally accepted as indicators of the overall project costs and finish time, they have often been the subject of criticism, mostly because of the reliability of the CPI and SPI indicators. Some of the criticism includes: the final cost variance is always greater than its value at $20 \%$ project completion; cost performance index value does not change by more than $10 \%$ compared to its value at $20 \%$ of project completion and is usually negative. Finally, the total estimated cost based on the CPI is usually less than actual at the end (Christensen, 1999). This criticism resulted in adjusting the formula for calculating the total cost of the project, so that $\mathrm{EAC}=\mathrm{BAC} /(\mathrm{CPI} @$ $20 \% \pm 0.1$ ).

The issues related to predicting the completion time of the project are usually related to the variance SV, and its SPI indicator. In essence, earned value methodology defines time indicators indirectly through monetary or cost value. Accordingly, it is not possible to unambiguously assess the temporal progress of the project. Problems arise when specific project activities have parallel execution rather than in the order. In such situations, certain non-critical activities can be delayed, and critical activities can be executed faster than planned, which altogether may lead to erroneous conclusions (Russell, 2008).

Another drawback associated with the time estimate is that with the progress of execution schedule variance tends to zero, and the schedule performance index to one. This indicates that project execution is on time, although it may be delayed in reality. In this sense, we can say that after a certain percentage of project execution, regardless of the project structure, the usability of SV and SPI indicators decreases significantly. This happens most often after larger part of the project $(2 / 3)$ is completed, which means that those indicators can be applied with certainty in the period when $15-70 \%$ of the project is completed.
In order to cope with these problems, the Lipke (2003) has improved the traditional approach by introducing two additional variables: Earned Schedule (ES) and the Actual Time (AT). ES indicator is calculated by projecting the value of the BCWP on BCWS at a particular moment of realization (AT) the time when the current BCWP according to the plan should have been achieved. This moment can precede or follow AT, depending on whether the execution of the project is delayed or goes forward according to the plan. The formula for calculating the earned schedule is: $\mathrm{EC}=\mathrm{C}+((\mathrm{BCWP}(€)-\mathrm{BCWS}(\mathrm{t})) /$ $(B C W S(t+1)-B C W S(t))$. The difference and the ratio of ES and AT provide two new indicators $S V(t)$ and SPI ( $t$ ), which can be used throughout the project's life cycle. In this case, the total estimated time of the project $\mathrm{EAC}(\mathrm{t})=\mathrm{D} / \mathrm{SPI}(\mathrm{t})$ (Lipke, 2003).

Several researchers have tried to test the existing approaches and find new ways to improve accuracy of predictions, such as development of statistical and fuzzy models. Vandevoorde and Vanhoucke (2006) have tested several existing methods and revealed that only the earned schedule showed satisfying and reliable results throughout the whole project duration. Ponz-Tienda et al. (2012) presented comprehensive and robust approach to fuzzy scheduling and earned value management of construction projects. Naeni et al. (2011) developed earned value model based on the fuzzy logic in order to develop and analyze the earned value indices, and cost and time estimates at completion under certain level of uncertainty.

Narbaev and De Marco (2014) attempted to overcome limitations of the traditional EVM and proposed an earned schedule-based regression model to improve cost estimate at completion. Colin and Vanhoucke (2014) proposed statistical project control procedure which sets tolerance limits to improve discriminative power between progress situations that are either statistically likely or less likely to occur under the project baseline schedule. Lipke et al. (2009) also applied statistical methods to EVM and ES performance indexes and found the proposed forecasting method to be sufficiently reliable.

\section{CASE STUDY ANALYSIS}

This section provides a real case study which illustrates the way in which the earned value methodology, as described in the previous section, can be used as an effective tool for measuring the project performance and prediction of total cost and execution time of the 
construction project. Particular residential/commercial construction project was chosen for demonstration purposes, since in the planning and execution phase, experienced project team fully implemented processes necessary for EVM application, which primarily involves the existence of appropriate organizations and reliable input data.

The selected project involved the construction works on the construction of residential/commercial building in the municipality of Zemun, near Belgrade. Most of the work was carried out by the main contractor (including plumbing, electrical and HVAC system), while subcontractors were engaged in individual works such as groundwork, ceramic, floor, facade and paintwork. The total planned value of the project amounted to $€ 5,282,117$, with the total scheduled duration of 15 months, from March 2013 to May 2014.

The project was undertaken under a fixed price (lump-sum) contract, and payments were done on a monthly basis upon completion and receipt of the situation. In order to enable the appropriate planning and monitoring of project execution using the EVM, the project was broken down into almost 900 single project activities in the five-level WBS diagram. Project activity or project phase was considered completed only when fully completed (100\%). Based on the monthly progress reports, the project team calculated the key indicators of EVM - variance, performance indexes and assessed the overall costs and time. Table 1 presents

\begin{tabular}{cccccccc}
\hline & Mar, 2013 & Apr, 2013 & May, 2013 & Aug, 2013 & Nov, 2013 & Feb, 2014 & May, 2014 \\
\hline BCWS & 110,228 & 497,774 & $1,052,478$ & $2,332,164$ & $3,485,056$ & $4,721,903$ & $5,282,117$ \\
\hline BCWP & 35,205 & 248,997 & $1,049,230$ & $2,198,948$ & $3,286,550$ & $4,650,712$ & $5,282,117$ \\
\hline ACWP & 140,285 & 513,197 & $1,085,507$ & $2,289,053$ & $3,382,895$ & $4,790,741$ & $5,450,125$ \\
\hline CV & $-105,079$ & $-264,200$ & $-36,277$ & $-90,105$ & $-96,345$ & $-140,029$ & $-168,008$ \\
\hline CPI & 0.251 & 0.485 & 0.967 & 0.961 & 0.972 & 0.971 & 0.969 \\
\hline EAC & $21,048,049$ & $10,886,762$ & $5,464,746$ & $5,498,560$ & $5,436,962$ & $5,441,157$ & $5,450,125$ \\
\hline & & & & & & \\
\hline ES & 0.32 & 1.36 & 2.99 & 5.71 & 8.51 & 11.86 & 15.00 \\
\hline AT & 1 & 2 & 3 & 6 & 9 & 12 & 15 \\
\hline SV(t) & -0.681 & -0.642 & -0.006 & -0.286 & -0.490 & -0.140 & 0.000 \\
\hline SPI(t) & 0.319 & 0.679 & 0.998 & 0.952 & 0.946 & 0.988 & 1.000 \\
\hline EAC(t) & 46.97 & 22.09 & 15.03 & 15.75 & 15.86 & 15.18 & 15.00 \\
\hline
\end{tabular}

Table 1. Estimated total project costs and time using the earned value method

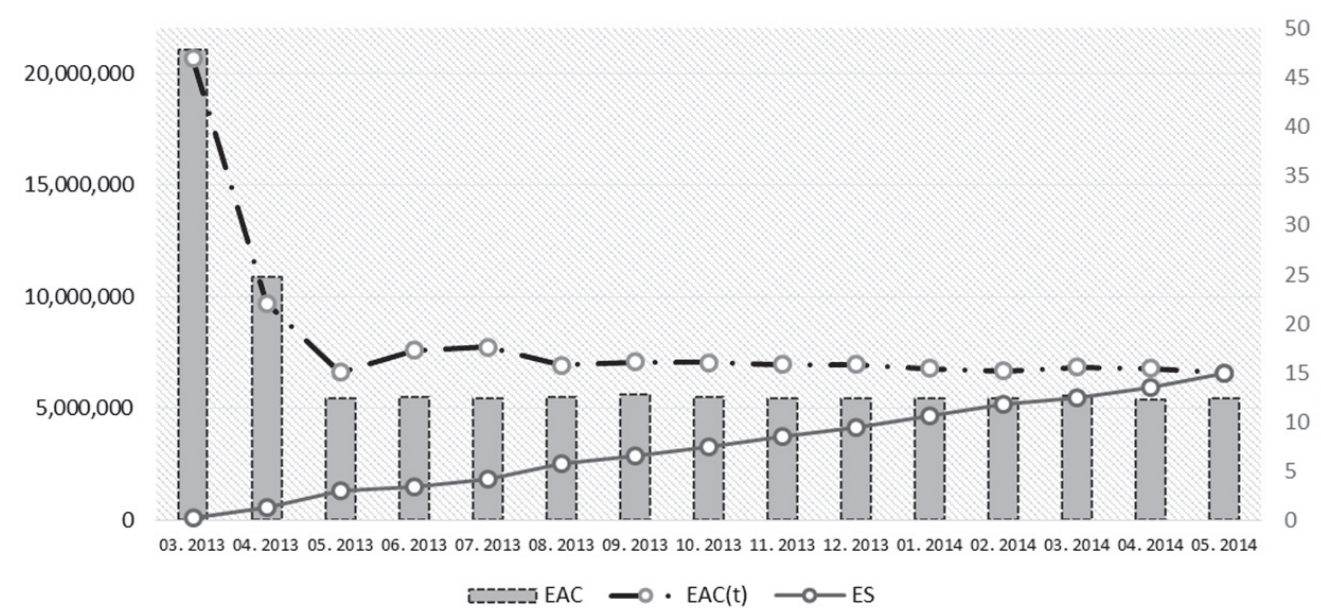


the summary of project results achieved during the execution phase.

Table 1 reveals that the project was executed on time and over budget by around 170,000 EUR. It can also be seen that after $20 \%$ of the project execution (which in this case equals to three months), cost performance index (CPI) stabilizes between 0.96-0.97, which usually tends to unity due to additional efforts to complete the project on time. In all intervals, Estimate at Completion (EAC) was calculated. After three months, $19.86 \%$ of the planned work was executed, the actual cost accounted to $20.55 \%$ for the total budget, and with $3.46 \%$ predicted budget exceedance. In this sense, the overall cost assessment ranged from $102.7 \%$ to $106.3 \%$ of the original budget, which was exceeded at the end by $3.18 \%$.

Similar to monitoring of costs performance, earned value was calculated for schedule indicators - ES and EAC ( $t$ ). When calculating the value of ES for the first and last period, the value of $\mathrm{C}$ for the first period is equal to zero, and for the last is equal to 15 , which is the total planned duration of the project. It can be seen in Figure 3 that the estimated time for project execution stabilizes between 15 and 16 months after three months, which proved to be very accurate in relation to the actual project duration. Besides that, estimated total costs at $20 \%$ of execution ( $€ 5,464,746)$ proved to be very reliable in relation to the total actual cost at the end of the project $(€ 5,450,125)$.

\section{CONCLUSION}

This paper aimed to show the theoretical and practical dimension of performance measurement on a small-scale construction project using the earned value methodology, and thereby contribute to its wider practical application. In addition to presented significance of the method and numerous advantages described in the theoretical part, particular attention was drawn to certain issues and problems that may occur during application and potential ways in which these disadvantages can be overcome. This is primarily related to organizational prerequisites that must be provided before the methodology is applied, as well as certain issues and problems that can occur in forecasting of the total time of project execution.

Application and adaptability of the EVM method are illustrated in a form of a case study, which demonstrated that the EVM represents a reliable means for total project cost and duration prediction, already in the early stages of project implementation. Regardless of the type and size of the construction project, and with a well-structured plan and appropriate monitoring approach, the earned value method can serve as an early warning tool to project teams, showing that certain part of the project is not being executed according to plan, and thus prevent greater consequences in terms of sliding cost, time or scope.

\section{REFERENCES}

Assaf, S.A., \& Al-Hejji, S. (2006). Causes of delay in large construction projects. International Journal of Project Management, 24(4), 349-357. doi:10.1016/j.ijproman.2005.11.010.

Avlijaš, R., \& Avlijaš, G. (2010). Upravljanje projektom. Beograd: Univerzitet Singidunum. In Serbian.

Christensen, D.S., \& Templin, C. (2002). EAC evaluation methods: do they still work. Acquisition Review Quarterly, 9, 105-116.

Christensen, D.S. (1998). Cost and benefits of earned value management process. Acquisition Review Quarterly, 5, 372-386.

Christensen, D.S. (1999). Using the earned value cost management report to evaluate the contractor's estimate at completion. Acquisition Review Quarterly, 19, 283-296.

Christensen, D.S., \& Heise, S. (1993). Cost performance index stability. National Contract Management Journal, 25, 7-15.

Colin, J., \& Vanhoucke, M. (2014). Setting tolerance limits for statistical project control using earned value management. Omega, 49, 107-122. doi:10.1016/j.omega.2014.06.001.

De Marco, A., \& Narbaev, T. (2013). Earned value-based performance monitoring of facility construction projects. Journal of Facilities Management, 11(1), 69-80. doi:10.1108/14725961311301475.

Doloi, H., Sawhney, A., Iyer, K.C., \& Rentala, S. (2012). Analysing factors affecting delays in Indian construction projects. International Journal of Project Management, 30(4), 479-489. doi: 10.1016/j.ijproman.2005.11.010.

Fleming, Q.W., \& Koppelman, J.M. (2003). What's your project's real price tag. Harvard Business Review, 20-21. doi:10.1225/F0309C.

Flyvbjerg, B., Holm, M.S., \& Buhl, S. (2002). Underestimating costs in public works projects: Error or lie. Journal of the American Planning Association, 68(3), 279-295. doi:10.1080/01944360208976273.

Kim, E., Wells, W.G., \& Duffey, M.R. (2003). A model for effective implementation of Earned Value Management methodology. International Journal of Project Management, 21(5), 375-382. doi: 10.1016/j.ijproman.2005.11.010.

Kwak, Y.H., \& Anbari, F.T. (2012). History, practices, and future of earned value management in government: Perspectives from NASA. Project Management Journal, 43(1), 77-90. doi:10.1002/pmj.20272. 
Lipke, W. (2003). Schedule is different. Retrieved Jun 21, 2015, from http://www.earnedschedule.com/Docs/Schedule\%20is\%20Different.pdf

Lipke, W., Zwikael, O., Henderson, K., \& Anbari, F. (2009). Prediction of project outcome: The application of statistical methods to earned value management and earned schedule performance indexes. International Journal of Project Management, 27(4), 400-407. doi:10.1016/j.ijproman.2008.02.009.

Mladenović, I. (2013). Građevinarstvo kao industrijski sektor u funkciji oporavka privrede Republike Srbije. Ekonomski horizonti, 15(3), 245-256. doi:10.5937/ekonhor1303245M

Naeni, L.M., Shadrokh, S., \& Salehipour, A. (2011). A fuzzy approach for the earned value management. International Journal of Project Management, 29(6), 764-772. doi:10.1016/j.ijproman.2008.02.009.

Narbaev, T., \& De Marco, A. (2014). An earned schedulebased regression model to improve cost estimate at completion. International Journal of Project Management, 32(6), 1007-1018. doi:10.1016/j.ijproman.2008.02.009.

Project Management Institute. (2011). Practice standard for earned value management. Newtown Square, PA: Project Management Institute.

Project Management Institute. (2013). A guide to the project management body of knowledge. Newtown Square, PA: Project Management Institute.

Ponz-Tienda, J. L., Pellicer, E., \& Yepes, V. (2012). Complete fuzzy scheduling and fuzzy earned value management in construction projects. Journal of Zhejiang University SCIENCE A: Applied Physics \& Engineering, 13(1), 56-68. doi:10.1631/jzus.A1100160.
Russell, S. (2008). Earned value management: uses and misuses. Air Force Journal of Logistics, 32(2), 85-91.

Serbian Chamber of Commerce. (2015). Gradevinarstvo, industrija gradevinskog materijala $i$ stambena privreda. Retrieved March 20, 2015 from http://www.pks.rs/PrivredaSrbije.aspx?id=7\&p=2

Statistical Office of the Republic of Serbia. (2015). Total value of executed construction works. Retrieved Jun 21, 2015, from http://webrzs.stat.gov.rs/WebSite/

Trbović, A., Vonnegut, A., Brnabić, A., Valentine, S., \& Seas, W. (2007). Konkurentni potencijal 11 grana srpske privrede. Ekonomska misao: časopis Saveza Ekonomista Srbije za Pitanja Ekonomske Teorije i Prakse, 40(1-2), 52-66.

Vandevoorde, S., \& Vanhoucke, M. (2006). A comparison of different project duration forecasting methods using earned value metrics. International Journal of Project Management, 24(4), 289-302. doi:10.1016/j.ijproman.2005.10.004.

Wilson, B., Ariyachandra, T., \& Frolick, M. (2013). Earned value management systems: Challenges and future direction. Journal of Integrated Enterprise Systems, 2(1), 9-17.

Yang, H., Yeung, J.F.Y., Chan, A.P.C., Chiang, Y.H., \& Chan, D.W.M. (2010). A critical review of performance measurement in construction. Journal of Facilities Management, 8(4), 269-284. doi:10.1108/14725961011078981.

\section{PRIMENA METODE OSTVARENE VREDNOSTI U PRAĆENJU MANJIH GRAĐEVINSKIH PROJEKATA}

\section{Rezime:}

Primena metode ostvarene vrednosti u Srbiji značajno zaostaje za drugim razvijenijim privredama, bez obzira na to što se pokazala kao veoma upotrebljiv i prilagodljiv alat za predviđanje ukupnih troškova i vremena realizacije građevinskih projekata. Ovaj rad trebalo bi da doprinese široj primeni metode upravljanja ostvarenom vrednošću (EVM), kao veoma praktičnoj metrici koja se može koristi za praćenje manjih građevinskih projekata. Pregled literature otkriva kako se metoda razvila kao osnovno sredstvo za praćenje građevinskih projekata i upućuje na specifične probleme vezane za njenu primenu. Kako bi se ukazalo na sve pogodnosti metode ostvarene vrednosti u cilju uspešnog praćenja učinka na manjim građevinskim projektima, upotrebljivost metodologije prikazana je u vidu studije slučaja.

\section{Ključne reči:}

ostvarena vrednost, upravljanje projektima, građevinarstvo. 